\title{
Paul's Teachings on All-Sufficiency of Jesus Christ for Salvation in Colossians 2:8-3:5 in Relation to Christianity in Africa
}

\author{
Valentine Chukwujekwu Mbachi \\ https://dx.doi.org/10.4314/jrhr.v13i1.15
}

\section{Abstract}

This article examines Pauls teaching on all-sufficiency of Jesus Christ for salvation in relation to Christianity in Africa. The approach has been analytical or qualitative. The historical-critical method and contextual tools are used in the interpretation of the biblical text. The study reveals that the Colossian situation to a large extent depicts the life of the Church in Africa today. Christ must be proclaimed not just as the Saviour of the soul, but as the Lord of lords, the king of kings, Victor, Redeemer, Deliverer, Healer, Provider, Unique and AllSufficient God lest like Colossian and African syncretists, many people may turn to other answers such as magic, charms, amulets, rituals and other occult practices for protection against the enslaving and binding spirits.

Keywords: Teaching, All-sufficiency, Salvation, Relation, Christianity

\section{Introduction}

Perhaps not surprisingly, the distinctive drive of the language and theology of Paul in Colossians has offered me an informative pattern for the Church's encounter with syncretism- that mixing of incompatible religious ideas and practices- today, and particularly as it relates to African context. It is quite impossible to study the epistle of Colossians without encountering the likeness between the situation Paul addressed in Colossae and that of Africa. The message of this very old correspondence speaks with uncommon strength to the 
contemporary African cultures where Indigenous Religion inspires fear or the worship and veneration of ancestors pits rivals against the lordship and all-sufficiency of Christ. Of a particular interest is Paul's culture-sensitive and non-forceful way of doing theology which like a thread runs throughout the book, is considered, as a very big legacy for a "theological task in every generation and culture".

Conceivably, the errors peddled by the heretics which was threatened to ruin the Church at Colossae resulted from poor understanding of the task and mission of Christ which also points to improper understanding of the salvation that is in Jesus Christ. In the thinking of the false teachers, redemption (apolutrosin) in Christ had to be supplemented with other means such as legal regulations, angel worship, ascetic and ritual practices in order to achieve the intended result. Paul counters this teaching by telling the Colossians that Christ is not only ultimate; $\mathrm{He}$ is also wholly adequate for their present experience of salvation. No supplements are required. Believers at Colossae have no need, therefore to pledge allegiance to any lesser supernatural beings or angel-intermediary given that "Christ reigns supreme over every ruler and authority". This article aims to examine the "additions" or "supplements" to Christ" the false teachers wanted the Colossians to accept and then see how it relates to the African context. It is qualitative in approach. The historical-critical method and contextual tools are used in the interpretation of the biblical text.

\section{Issues at Stake in the Church at Colossae}

The teachings of the heretics were not laid out as an organised piece of instructions in neat piles. So, to get the glimpse of the issue Paul was confronting at Colossae, we need to get into the text itself. We shall now try to piece together the teachings of the heretics from the responses Paul gave to them:

(a). Paul tends to anchor the teachings of the heretics to a mere shadow; the real truth is in Christ (Col. 2:17). A religion which is 
rooted in external observances and ritualism is only a chaff of the real religion; real religion is relationship with Christ.

(b). Paul reduces the teachings of the heretics to a mere false humility (Col. 2: 18, 23). The way to God accommodates no intermediaries. It is always open and accessible to all and sundry, and is made possible through the vicarious deeds of Christ on the cross.

(c). Paul considers the teachings of the heretics as a teaching that merely gives vent to pride (Col. 2:18, 23). The basic tenet of the truth of Christianity is that those who think that they are good are never really good. Hence, the injunction, to always prefer others better to oneself.

(d). Paul considers the teachings of the heretics as a bait to enslavement and captivity and not as a means of Christian freedom. Christian freedom surges forth not from ritual and legalistic observances, not by controlling desires by rules and regulations, but from nailing to the cross all manner of inordinate desires and breaking forth of godly desires as a result of having Jesus as a living reality in one's life.

(e) Paul perceives the teachings of the heretics as the gospel of "additions" or "supplements" to Christ. For the heretics, the truth of the gospel and its simplicity should be augmented with some kind of philosophical stuff. But, Paul passionately stood against any philosophy or fanciful speculation that seeks to undercut the high Christology he advocated. He enjoins the Colossians to stand firm on Christ who is the solid and sure foundation of their faith

(f) It was the message of the heretics that Colossians were still under the influence of the elemental spirits of the universe, especially of the 
stars and planets. Consequent upon this, they needed a special knowledge to be free. Paul teaches that when we have experiential knowledge of Jesus Christ, we don't need to investigate or experiment other religions, cults, or unbiblical philosophies.

(g) False teachers were seeking to impose circumcision upon the Colossian Christians. They were teaching that work has to complete what faith had started. However, Paul refutes this teaching by affirming that circumcision is "a spiritual act whereby Christ cuts away the old unregenerate nature of rebellion against God and imparts to the Christian his spiritual and resurrection life". For Paul, circumcision is of the heart

(h)Errorists wanted to introduce regulatory rules of abstinence. They intended to lay down 'all manner of rules and regulations about what might be eaten and drunk and about what days to be observed as festivals and fasts'. As against the inclusion of Jewish ascetic dietary rules as being necessary for salvation, Paul teaches that a Christian is no more a captive to any legal and ceremonial obligations.

(i) The Colossian heretics were seeking to impose the worship of angels on them. 'They were teaching that Jesus was only one of many intermediaries between God and humans, and that these intermediaries must receive their worship'. To Paul, calling on angels would be to deny Jesus Christ as the supreme and sufficient Head of the Church as well as to render him a victim of divine creative ingenuity.

Having gone through these issues listed above Mbachi and Uchendu (2021) affirm:

Two things can be highlighted: (a) The content of the heresy apparently, are many and vary. Perhaps, it contains a combination of Jewish legalism, Greek speculation, and the 
mysticism of the Orient. Perhaps, some of the elements later graduated into Gnosticism and, (b) one thing that is so conspicuous in the false teachers' message is that Jesus Christ, his teachings and work were not in themselves sufficient for salvation. Sequel to this, they came up with the Philosophy of additions. As far as they were concerned, Jesus Christ is not sufficient for the salvation of humankind thereby necessitating the worship of other spiritual beings and forces in addition to him. (p. 26).

\section{Features of the Additive Elements to Christ}

- Sham and hollow religiosity manifested in external observances, legalism and ritualism;

- False humility manifested in angel worship as an intermediary;

- Vent to sinful pride;

- Dominated by elemental spirits of the universe, especially, the stars and the planets;

- Acts of circumcision;

- Regulatory rules of abstinence;

- Low view and miniature understanding of Jesus Christ; and

- Sense of inadequacy and incompleteness in the sole worship of Jesus Christ.

\section{Historical Perspective}

Many attempts have been made over the years to fish out the identity of the heretics, but their personality is too difficult to nail down. Down the memory lane, opinions vary. While some scholars in nineteenth century like F. C. Baur took the heresy amongst other things for incipient Gnosticism, some scholars in the twentieth century developed and shaped one or more ideas from the nineteenth century. Scholars like O'Brien (1982), and Barclay (2009) have tried to root the false teachings in some form of early Gnosticism, in Greek 
philosophy, or in Jewish mysticism, all without full success. Flemming (2005) thinks that it is better to consider the false teachings at Colossae as resulting from a combination of various sources. The sources amongst other things could be Jewish legalism, Greek speculation, the mysticism of the Orient and early traces of Gnosticism. Mbachi and Uchendu (2021) discuss the scholarly views cum historical perspective on heretical teachings at Colossae and finally commented that:

(a) "It helps us to appreciate the rich cultural backgrounds that played into the problems Paul was addressing in Colossae;

(b) "It helps us to find out for ourselves that the identity of the false teachers is not easy to specifically pin down; and

(c) "That the most probably way to come to grip with the problem at Colossae is to go to the biblical text itself" (p. 27).

\section{Exegesis and Discussion}

The heretics in Colossae denied the uniqueness and all-sufficiency of Jesus Christ and held that he was just one among many manifestations of God. They proffered it among others as a good reason to serve other divine powers in addition to Christ. Paul intensely warns the Colossians against allowing themselves to be enslaved (sulagogon). Actually, what was going on in Colossae was a sheer deception promulgated by fanciful intellectualism or concocted empty fraud. Sulagogon could be used of 'a slave dealer carrying the people of a conquered nation into slavery'. Perhaps, by the use of this term, Paul was warning the Colossians against people who through philosophy and empty deceit could carry them off as spoil from the truth into error and consequent slavery. Arnold (1992) argues that "the Colossian philosophy" in its encapsulated form can be seen as 'a combination of Phrygian folk belief, local folk Judaism, and Christianity'. He further goes on to aver six characteristic themes in the local folk belief of the Phrygian people which include: a tendency 
towards henotheism, an emphasis on divine intermediaries, a strong belief in dangerous spirits and powers, an appeal to intermediaries for protection and deliverance, and a prominent role for magic and ecstatic forms of worship. Harris (2010) notes that Paul is opposed to those false teachers given that "their philosophy" belongs to the world makes Christ of none effect, demonic and the teachers of the "philosophy" are improper judges". Paul goes on to declare that in Christ "all the pleroma (fullness) of deity dwells bodily." Katoikei (permanently dwells) has the import of permanency. Katoikein (permanent residence) is distinguished from paroikein (temporary residence). In other words, it is in Christ, and Christ alone, that the sum total of the fullness of the Godhead, no part or aspect expected, permanently resides in bodily form. Paul's use of the term pleroma (fullness) raises an interesting question. Has he borrowed it from the heretics and suffused it with new Christological content? There is no way one can find out. For Wright (1986), the Colossians have no need to pledge allegiance to any lesser supernatural beings or angelintermediaries. This is simply because Christ is 'not just one among the many competing gods or powers'. He reigns supreme over every ruler and authority (Col. 1:10, 2:9). The totality of God, the entirety of His attributes and divinity, is pleased to dwell in Christ. For Paul, Christ has set us free from all elemental spirits of the universe. The Colossians had been rescued from the dark domain of satanic powers and brought over to God's Kingdom (Col. 1:13). Furthermore, the dreaded demonic powers and spirit-beings which had held their lives captive in a web of superstitious were being forced to relinquish their grip. Christ the great liberator had broken their powers on the cross and won a once-for-all resounding victory over them. Martins (1974) concurs that the death of Christ means to Christians death to all the evil powers of the universe $(2: 20)$, and the resurrection of Jesus means triumph over all the dreadful satanic powers which they previously feared as "pagans". 
According to Paul, the angelic hierarchies and astral powers created by the cosmic Christ had been brought to subjection on the cross. A continued recognition of these powers not only denies the victory won by Christ on the cross but also robs (katabrabeuo) Christians of their hope in Christ. Paul reminds the Colossians that they have died to "elemental spirits of the universe" (stoicheiatoukosmou). Lohse (1971) thinks that in the light of the Colossian philosophy, this term probably refers to the astral and cosmic powers that were thought to hold a sinister influence over the daily lives of human beings. Stoicheia has the idea of elementary instruction in any subject. The false teachers claimed to be giving the Colossians advanced and profound knowledge of overcoming satanic powers. Nevertheless, any other knowledge which does not focus one's attention on Christ alone is rudimentary. Christ is the only means of the divine Presence. Stoicheia also refers to the elemental spirits of the world like stars, planets, divinities or spirit-beings. The heretics at Colossae taught that if humans know the right pass-words and the right formulae they might escape from fatalistic influence of these demonic powers. However, Paul insists that Colossians needed nothing other than Christ, who is the fullness of God and the origin of creation, to overcome all cosmic powers.

Christ tears us from the powers of darkness and translates us into his dominion through faith and baptism which is his circumcision. In Christ, the redeemed have completeness, perfection and freedom from the guilty past. Jesus has cancelled the legalistic documents that witness against us, nailing them to the cross. He has once-for-all abolished servitude to the law and superstitions. The way to true life is by union with Christ. Anyone who through faith has been baptised into Christ, who is the Lord over all, belongs to the Head who is supreme over all. Paul urges the Colossian Christians to resist every attempt to impose any legal system, superstitions and taboos on them. The Mosaic Law and all "pagan" superstitions belonged to the age of 
shadows and the dead past. Christians should refrain from practising self-abasement (tapeino-phrosune) and worship of angels (threskeia). Their pneumatic visions, sensual pride and false humility will only sever them from Christ, who is the only true source of life eternal. The heretics forbade the eating and touching of certain foods, but the temporary nature of these things shows the pointlessness of their prohibition. The self-imposed devotions to angels and spirits, only has a mere appearance of wisdom. The failure of the whole scheme is that it could not stop the indulgence of the flesh and does no honour to the body which God made for his glory. Since they have died and risen with Christ, they should live as those who have died to those things. Christians have their eternal destiny hid with Christ in God. Despite the fact that Paul speaks of the transcendent pre-eminence and uniqueness of Christ and fullness of life that Christians have in him, the ultimate perfection of those things is still future and concealed in the eternal wisdom of God. However, the parousia will mark Christ's ultimate victory and it is then that the whole creation will share in the fullness of Christ's triumphant redemption.

\section{The Situation in Africa}

There is no denying the fact that the Colossian situation to a large extent depicts the life of the Church in Africa today. African world is still strongly dominated by the ideas of the influence of divinities, spirits, ancestors, witches and wizards. Natural forces like rain, thunder, lightning and wind have spiritual powers controlling them. Rivers, lakes, mountains, groves, and trees are occupied by spirits which can either bless or harm human beings. The African man lives under constant fears in a world invested by spirits and demons. Traditionally, nobody can act without consulting the family god or divinity. These gods and spirits control access to the divine Presence. The belief in the existence and potency of these powers is neither the resultant effect of ignorance nor the means of filling the gaps that 
cannot yet be explained by science. Abogunrin (2002) captures it well when he said that "the wearing and use of charms, rings, and amulets by the various categories of people, regardless of their education, reveals the real nature of the situation". But the Bible teaches that these spirits and demons are created spiritual beings though there origin is not clear. Some people think that demons are the spirits of departed people. At any rate, it may be safe to aver that demons can pose as deceased by becoming visible in a form that resembles them. Many Africans claim to have received instructions or directions from deceased family members, passed on to them either physically or in a dream, despite the biblical teachings against communicating with the dead.

Demons and all these evil spirits fight against God and tend to steal devotion away from Him to themselves. Activities such as conferring with the dead, worshipping and sacrificing to idols and ancestors result in contact with demons (Deut. 32:17; Rev.9:20). Such worship, may, however, produce results, for demons have power to perform miracles, to mobilize the kings of the world and to fight against God Almighty (Rev. 16:13-14). Demons inspire false doctrines and teachings and give worldly wisdom, which is sensual and demonic (Eph. 2:2; 1Tim. 4:1; Jam.3:15). Believers can only take comfort in the fact that Christ has triumphed over and disarmed those powers on the cross. Afflictions by Satan or demons can only come as a result of God's permit. Christians should therefore enjoy the freedom whereby Jesus had set them free and no longer be enslaved by these elemental forces of darkness.

The belief in angelic intermediaries among the independent Churches in Africa is widespread. Prayers are offered through angels to God, especially Michael the Arch-angel. Every service begins with the invocation of the name of Jesus and Holy Michael. Angels are called upon to drive away evil spirits and to protect worshipers. The angels have hierarchies and two of the most important four are 
Michael and Gabriel. In some of the Churches, rituals, palm-reading and sacrifices are still prescribed and performed as in traditional religion. They keep special fasts, holy days, have special prayers on mountains, riversides, groves and near the sea. Certain Hebrew names of God are believed to be potent and are used in prayers along with some incantations from the Egyptian magic book called "Six and Seven Books of Moses". The book is said to contain the secrets behind the powers of Moses and other prophets. In that book, one can learn how to communicate with various angels.

Furthermore, it is not unusual for the Hebrew and other esoteric names of God and the crucifix to be either written or hanged on the walls of the house or Church as a means of protection. Ritual baths and washings are common. Members spend much money on candles and incense which not only make prayers efficacious but also drive away evil spirits and attract good spirits. There are also special uniforms for worship and prayers. The "jingling of the bell three times before prayer is to invite God, Jesus and the angels to join in worship". The psalms are believed to possess some magical powers if used along with other things as prescribed. The taboos, quite unrelated to morals, are also many. Most of the Churches are led by semi-illiterates whose knowledge of the Scriptures is very limited. Unquestionably, the ministry of angels plays a leading role in the life of the Church in Africa as we have seen above, especially in the African Independent Churches. This should rather not raise one's eye brows given the fact that ministry of the angels have been in the fore front throughout the history of the Church. The ministry of angels is not extinct today. What then is the correct teaching of the Bible concerning the angels?

The word "angel" means God's messenger. In other words, angels are God's emissaries. They are among the created creatures (Psm. 148-2-5; Col.1:16; Heb. 1:14). As messengers, they deliver God's messages to humans and promote God's purposes in the world. 
They act to accomplish God's will in the earth and may be visible to the eyes in human form (Gen. 18:2, 16; Ezek. 9:2). Sometimes, but not always, we are told their names, for example, Gabriel was mentioned in Daniel 8:16 and Luke 1: 19, whereas Michael was mentioned in Daniel 10:18. Angels are also sent by God to protect, encourage and provide for believers and also assist in answering their prayers (Dan. 9:20-27). Angels have been implicated in escorting believers to heaven (Lk. 16:22), and executing God's judgment on evil ones (Gen. 9:12-13; Ezek. 9:1-11; Matt. 13: 39-42; Acts 12:23; Rev. 8:2-12). As created beings, they are not themselves divine or independent rather they are subordinate to God and drive their powers from Him. Being living creatures, they are not to receive any worship from humans. They are of a higher order than human beings (Heb. $2: 7)$, and are thus more powerful and are not subject to earthly limitations. Like all other human beings, angels possess free will and knowledge (Mk. 13:32). And like humans, some angels have used this free will to revolt against God (2 Pet. 2:4; Jude 6). Little wonder, then, that the Bible differentiates between good and bad angels, depending on whether they are obedient or disobedient to God. True angels not only worship God but also insist that only God is worthy of worship and refuse any worship from humans. Putting everything into consideration, therefore, angels are created beings and God's messengers. They should neither be worshipped by humans nor receive orders from them. Claimants who boast of their knowledge of the secret names of the angels should therefore be treated as nothing other than impostors and charlatans.

In the African context, the practices that are going on can be put into a capsule form thus:

- angel and ancestor worship and veneration;

- wearing of amulets, crucifix and aprons for protection;

- ritual baths and washings;

- wearing of special uniforms for worship; 
- burning of candles and incense to drive away evil spirits;

- use of magical books;

- observances of certain days;

- invocation of angels and saints before and during worship;

- prayers are offered to God through intermediaries like angels, ancestors and other divinities;

- performance of sacrifices; and

- consultation of diviners, enchanters and sorcerers.

In other words, when one critically studies the situation in Africa, one is likely to agree with me that the prevailing situation admits inadequate role of Christ. It spells out a lack of understanding of the salvation that is available in Christ Jesus. Like the situation Paul encountered in Colossae, redemption in Christ needed to be augmented with other means- ascetic and ritual practices, angel worship, legal regulations and visionary experiences- in order to be truly effective. Like Colossians, Africans should realize that Christ is not only ultimate, he is even more than adequate their present experience of salvation. They should realize that with Christ as their Lord and Saviour, no supplement is required.

Paul had spelt out to the Colossians the wholeness of the redemption believers have received from Christ. To them he affirms that Christians have participated in the Easter event. With this participation in Christ's death and resurrection, Christians have come to share in the fullness of resurrection life, and particularly, His deliverance from the tyranny of the elemental forces of darkness. This is precisely what the Christians in Africa needed to hear.

In Colossians 3:1-4 Paul teaches that Christians who have been raised with Christ can already participate in the heavenly elements where Christ is dignified at the right hand of God. Lincoln (1981) captures it correctly when he said that because the heavenly realm is the place where Christ is seated in a position of authority beside the Father, "nothing can prevent access to His realm and God's presence 
and there can be no basic insecurity about the salvation they have in Him" (p. 125). Their lives are now "hidden with Christ in God" (Col. 3:3) in a place of security and safety, protected from any menacing forces. So, the need to appropriate the salvation that is in Christ Jesus, as a matter of fact, cannot be overemphasized. When the Christian identifies with the vicarious deeds of Christ on the cross, the fullness of God- His power and grace- are bestowed on the Christian by virtue of his or her incorporation into Christ. As a result of the believers' link with the fullness of deity through Christ, there can be no deficiency that needs to be filled by further teachings, and practices offered by the charlatans and their vain speculations.

The situation, both in Colossae and Africa calls for Christian discipleship. Paul starts by saying that Christians should live in a way that is worthy of the Lord (Col. 1:10), and in the reality of God's gracious and saving action in Christ. As they "received Christ Jesus the Lord," they are now to "walk" in Him (Col. 2:6). Since they have been reconciled to Christ, they must continue on in holy living or else risk falling back into their old evil way of life (Col. 1:21-23). Flemming (2005) thinks that in "Colossians as elsewhere in Paul's letters, theology and ethics are interwoven and that nowhere is this apparent than in Colossians 3:1-4, which provides a Christological foundation for Paul's instruction in chapter 3 on living as a transformed community". Little wonder then, that Paul invites the Colossians to a new moral visualization, one that is determined by their cohesion with the victorious, glorious and exalted Lord, and their experience of crucifixion, death and risen with him (Col. 3:1,3). Consequently, they are to seek the "things that are above" and exchange what is earthly for what is heavenly $(\mathrm{Col} .3: 1-2,5)$. This perception entails a total reorientation of their existence, a radically different way of relating to the world. Colossians, as well as Africans must live no longer by the norms and values of the world, but by those of God's future heavenly kingdom (cf. Col. 2:20). The story of 
Christ, his death, resurrection, exaltation and return (Col.3:4), therefore become foundational to Colossians, and by extension Africans, not only for their redemption, but also for their holy life. While these are put in place the question of supplementary or "additions" do not arise but a realization of all-sufficiency of Jesus Christ in all realms of life.

\section{Caution for Christians in Africa}

As we have seen in the discussions above, the false teachers distorted the truth about Christ and ended up preaching a gospel of "additions" to Christ. Since they were not connected to Christ, they came up with a different Christ, different Spirit and different way of salvation. At any rate, the gospel truth is life-transforming. It can only be experienced as it is practiced. Jesus is the truth because he is the sole revelation of the Father who is the end and goal of Christian faith. There is an inseparable relationship between the truth and freedom as expressed by Jesus in John 8:32 "You shall know the truth and the truth shall set you free." Of course, at the message of Jesus is the reality of love, truth and grace. Christianity is a faith rooted in God's self-disclosure, concentrated and consummated in Jesus Christ. Jesus taught by his life, and none the least by his words; and it was his teachings, actions and sufferings as well as his deeds that apostles preached as gospel message, the Christian faith, belief and practises. Jesus is therefore the standard whom the Body of Christ must copy if she is to be faithful in her mission. Christ's lifestyle, his teachings, his power and experiences provide the pattern for the Church.

Christian lifestyle is conspicuously quite different from that of non-Christian. Rightly conceived, the Christian life is a process and in that regard, instant maturity is not anticipated. It may be safe to say that the Christian may have a new nature, but needless to say, he or she does not automatically have all good thoughts and right attitudes when he or she becomes the person in Christ. However, through 
Christian discipleship and sound biblical teachings, the Christian will grow by grace unto maturity.

On a more serious note, the Christian needs to take heed that he or she cannot reach up to God by following rules and rituals. At any rate, we should not misread and misinterpret Paul. Paul is not saying that all rules are bad. He is rather saying that no keeping of laws and rules will earn salvation. The good news is God's descent to man and not man's ascent to God. God in Christ reaches out to humankind. It is now incumbent on humans to respond. So you see, Christianity focusing on Christ's work is in sharp contrast to man-made religions that focus on human effort. Our salvation is not the resultant effect of discipline and rule keeping, but on the infinite power of Christ's death and his glorious resurrection. Therefore, we shall guard against false teachers by asking these questions derived from the Living Letters of the Life Application Bible:

(a). Does it stress man-made rules and taboos rather than God's grace;

(b). Does it foster a critical spirit about others, or does it exercise discipline discretely and lovingly;

(c). Does it stress formulas, secret knowledge or special visions more than Word of God;

(d). Does it elevate self-righteousness, honouring those who keep the rules, rather than elevating Christ;

(e). Does it neglect Christ's universal Church, claiming to be an elite group;

(f). Does it teach humiliation of the body as a means to spiritual growth rather than focusing on the growth of a person; and

(g). Does it disregard the family rather than holding it in high regard as the Bible does? (p. 154).

\section{Conclusion}

Paul vehemently declared as shadows, the mystical legalism of yearly observances of sabbatrianism, of circumcision, of religious festivals 
and of all other erroneous practices in comparison with the reality of Christ. He sounded stern warning against the danger of succumbing to self-humiliating tendencies and angel worship being peddled by the impostors and charlatans who are inflated with visions, filled with futile notions and failed to adhere to Christ, the source of the Church's life and the only way to God's presence. In Pauline thinking, Christians did not only die with Christ but they also rose with Him. Consequently, they are liberated from control of elemental spirits of the universe, from the old world order, from restrictive regulations that prohibit touching or eating certain things that are destined to perish when used, from bondage to merely human precepts and doctrines, from enforced ascetic disciplines that not only involve self-imposed devotion, flaunted humility, and harsh treatment of the body but are also totally ineffective in restraining flesh regulations.

The unique and universal Lordship of Jesus must remain the anchor and sure foundation of any theology that professes Christianity. The sound Biblical teachings must be restored in all the Churches. The conquest of Satan and his cohorts must not only be preached but also applied in pastoral counselling in all our Churches. Christ must be proclaimed not just as the Saviour of the soul, but as the Lord of lords, the king of kings, Victor, Redeemer, Deliverer, Healer, Provider, Unique and All-Sufficient God. It stands to reason that unless Christ is proclaimed as the One who has defeated all the evil powers of darkness and is able to liberate people from fear, like Colossian and African syncretists, many people may turn to other answers such as magic, charms, amulets, rituals and other occult practices for protection against the enslaving and binding spirits. 
Mbachi: Paul's Teachings on All-Sufficiency of Jesus Christ for Salvation in Colossians 2:8-3:5 in Relation to Christianity in Africa

\section{References}

Abogunrin, S .O. (2002). Total adequacy of Christ in African context.

Lecture notes. University of Ibadan, Ibadan

Arnold C. E (1996). The Colossian Syncretism: the Interface between Christianity and Folk Belief in Colossae. Grand Rapids, Michigan: Baker

Bandstra, A. J. (1974). "Did the Colossians errorists need a mediator?" In New Dimensions in New Testament Study 329-343. Edited by R. N. Longenecker and M. C. Tenny. Grand Rapids: Zondervan

Barclay, W. (2009). The letters to the Philippians, Colossians and Thessalonias. Bangalore: Theological Publications

Bornkamn, G. (1948). "Die haresie des kolosserbriefes", In Thologische Literaturzeitung, 73 11-20

Bruce, F. F. (1957). Ephesians and Colossians, NIC. Grand Rapids: Eerdmans

CE. (1992). Powers of Darkness: Principalities and Powers in Paul's letters. Downers Grove, IL: IVP

Dibelius, M. (1975). "The isis initiation in apuleius and related rites", Conflict at Colossae, ed. F. O. Francis and W. A. Meeks, $2^{\text {nd }}$ ed. SBLSBS 4, Missoula, Mont: Scholars

Eadie, J. Ed. (1979). A commentary on the Greek text of the Bible of Paul to the Colossians edited by W. Young. Grand Rapids, Michigan: Baker House

Flemming, D. (2005). Contexualization in the New Testament: Patterns for Theology and Mission. Downers Grove, Illinois: IVP Academic

Harris, M. J. (2010). Exegetical guide to the Greek New Testament:

Colossias and Philemon. Nashville, Tennessee: Academic Houlden, J.L. (1970). Paul's letters from prison. London: Peguin Lightfoot, J. B. (1879). St. Paul's epistles to the Colossians and to the Philemon, $3^{\text {rd }}$ ed. London: MacMillan 
Lincoln, A. T. (1981). Paradise Now and Not Yet: Studies in the Role of Heavenly Dimension in Paul's Thought with Special Reference to his Eschatology. Cambridge: Cambridge University Press

Lohse, E. (1971). Colossians and Philemon. translated by W. R. Poehlmann and R. J. Karris. Philadelphia: Fortress

Lyonnet, S. (1956). "L'etude du milieu litterire et l'exegese du Nouveau Testament: Les adversires de Paul a Colosses", Biblica $37 \quad 27-38$

Martins, R. P (1974). Reconciliation and forgiveness in the letters to the Colossians. In: Reconciliation and Hope, New Testament and Eschatology, edited by Banks RJ Exeter: The Paternoster

Mbachi, V. C \& John C. U. (2021). Paul's teaching on the uniqueness and supremacy of Christ in Colossians 1:12-23 and its implications for Christianity in Africa. On Knowing Humanity Journal 5(1), 25-33

Moule, C. F. D. (1968). The epistle of Paul to the Colossians and Philemon. Cambridge: Cambridge University Press

O'Brien, P. T. (1982). Colossians, Philemon. Word Bible Commentary 44, Waco, Tex: Word Books

Wright, T. N. (1986). The Epistles of Paul to Colossians and to Philemon: An Introduction and Commentary. Grand Rapids, Michigan: Eerdmans

Zan,J.L. (1970). Introduction to the New Testament. Grand Rapids: Eerdmans

Valentine Chukwujekwu Mbachi (PhD) is a lecturer in Department of Religion and Human Relations, Nnamdi Azikiwe University, Awka, Nigeria. 